\title{
APLIKASI SISTEM PAKAR DIAGNOSA PENYAKIT GIGI METODE FORWARD CHAINING DI UPTD KESEHATAN PUSKESMAS BANGIL
}

\author{
Kurniawan Wahyu Haryanto ${ }^{1}$, Ari Dwi Cahyono² \\ Teknik Informatika, STMIK Yadika Bangil, \\ email : kurniawan.wahyu@stmik-yadika.ac.id ${ }^{1}$, aridwicahyono92@gmail.com²
}

\begin{abstract}
ABSTRAKS
Gigi adalah organ yang sangat penting dan sangat vital keberadaannya. Oleh karenanya kesehatan gigi sangatlah penting. Sebagian besar masyarakat Indonesia, himbauan untuk periksa gigi enam bulan sekali lebih sering dianggap angin lalu, karena mereka lebih mementingkan kesehatan organ - organ tubuh yang lain. Padahal penyakit yang menyerang gigi dapat menimbulkan efek yang sangat berarti seperti misalnya masalah penampilan. Penelitian ini menerapkan ilmu komputer dibidang kedokteran terutama untuk masalah penyakit gigi di UPTD Kesehatan Puskesmas Bangil dengan menggunakan konsep sistem pakar. Sistem pakar merupakan suatu sistem berupa software komputer dimana komputer dibuat seakan - akan berpikir seperti seorang pakar atau ahli dalam bidangnya. Metode penelusuran yang digunakan adalah forward chaining, yaitu penelusuran dimana diketahui fakta yang ada untuk menunjang pengambilan kesimpulan. Sistem pakar ini memberikan kemudahan kepada pasien untuk melakukan konsultasi, memudahkan admin untuk mengelola data-data gejala beserta penyakitnya dan data pasien, dilihat dari hasil kuesioner yang menyatakan sangat bermanfaat, bisa dijadikan sebagai dokter sementara.
\end{abstract}

Kata Kunci : Sistem Pakar, Penyakit Gigi, Forward Chaining.

\begin{abstract}
Teeth are organs that are very important and very vital. Therefore dental health is very important. Most of the Indonesian people, the appeal for dental examinations every six months is more often considered a breeze then, because they are more concerned with the health of other organs. Though diseases that attack teeth can have a very significant effect such as appearance problems. This research applies computer science in the medical field, especially for dental disease problems at the UPTD Health Center in Bangil using the expert system concept. Expert system is a system in the form of computer software where the computer is made as if - will think like an expert or expert in the field. The search method used is forward chaining, which is a search where facts are known to support conclusions. This expert system makes it easy for patients to conduct consultations, making it easier for the admin to manage symptom data and their illnesses and patient data, judging from the results of the questionnaire which states that it is very useful, can be used as a temporary doctor.
\end{abstract}

Keywords: Expert System, Dental Disease, Forward Chaining.

\section{Pendahuluan}

\subsection{Latar Belakang}

Puskesmas dilahirkan tahun 1968 ketika dilangsungkan Rapat Kerja Kesehatan Nasional (Rakerkesnas) I di Jakarta, di mana dibicarakan upaya pengorganisasian sistem pelayanan kesehatan di tanah air, karena pelayanan kesehatan tingkat pertama pada waktu itu dirasakan kurang menguntungkan dan dari kegiatan-kegiatan seperti BKIA, BP, dan P4M (Pencegahan, Pemberantasan, Pembasmian Penyakit Menular ) dan sebagainya masih berjalan sendiri-sendiri dan tidak saling berhubungan. Melalui Rakerkesnas tersebut timbul gagasan untuk menyatukan semua pelayanan tingkat pertama ke dalam suatu organisasi yang dipercaya dan diberi nama Pusat Kesehatan Masyarakat (Puskesmas).

Pembangunan kesehatan mempunyai visi "Indonesia sehat" diantaranya dilaksanakan melalui pelayanan kesehatan oleh puskesmas dan rumah sakit. Selama ini pemerintah telah membangun puskesmas dan jaringannya di seluruh Indonesia rata-rata setiap kecamatan mempunyai puskesmas, hampir setiap 3 desa mempunyai 1 puskesmas pembantu.

Gigi adalah organ yang sangat penting dan sangat vital keberadaannya. Oleh karenanya kesehatan gigi sangatlah penting. Sebagian besar masyarakat Indonesia, himbauan untuk periksa gigi enam bulan sekali lebih sering dianggap angin lalu, karena mungkin mereka lebih mementingkan kesehatan organ - organ tubuh yang lain. Padahal penyakit yang menyerang gigi dapat menimbulkan efek yang sangat berarti seperti misalnya masalah penampilan.

Penelitian ini menerapkan ilmu komputer dibidang kedokteran terutama untuk masalah penyakit gigi di UPTD Kesehatan Puskesmas Bangil dengan menggunakan konsep sistem pakar. Sistem pakar merupakan suatu sistem berupa software komputer dimana komputer dibuat seakan-akan berpikir seperti seorang pakar atau ahli dalam bidangnya. Metode penelusuran yang digunakan adalah forward chaining, yaitu 
penelusuran dimana diketahui fakta $y=a n g$ ada untuk menunjang pengambilan kesimpulan. Fakta fakta yang digunakan dalam penelitian ini adalah gejala - gejala yang dirasakan pasien, sedangkan kesimpulannya adalah hasil diagnosa penyakit.

\subsection{Rumusan Masalah}

Berdasarkan uraian latar belakang di atas dapat dirumuskan masalah sebagai berikut :

a. Bagaimana caranya untuk membantu mendiagnosa penyakit gigi di lingkup wilayah kerja UPTD Kesehatan Puskesmas Bangil yang diderita oleh pasien?

b. Bagaimana solusi untuk mengatasi rendahnya kesadaran masyarakat untuk mendapatkan sumber informasi kesehatan gigi?

\subsection{Batasan Masalah}

Dalam suatu penelitian tentunya harus diberikan batasan masalah :

a. Metode yang digunakan merupakan metode forward chaining.

b. Aplikasi Sistem Pakar hanya untuk digunakan untuk mendiagnosa penyakit gigi.

c. Representasi penyakit gigi ini diterapkan berdasarkan tempat penelitian di UPTD Kesehatan Puskesmas Bangil.

\subsection{Tujuan Penelitian}

a. Membuat Sistem Pakar untuk pengobatan penyakit gigi di wilayah kerja UPTD Kesehatan Puskesmas Bangil, sehingga bisa mendiagnosa mudah diakses, perancangan dan pembangunan aplikasi ini.

b. Memberikan edukasi mengenai kesehatan gigi serta memberikan motivasi kepada masyarakat tentang merawat dan memelihara kesehatan gigi didalam sistem informasi.

\section{PEMBAHASAN}

2.1 Analisa Data

a. Pembentukan aturan (Rule) dan Tabel Gejala Dengan aturan (rule) dapat dengan mudah mengetahui hasil akhir nanti berdasarkan rule - rule yang ada. Berikut adalah aturan atau rule dalam diagnosa penyakit gigi. Tabel Gejala :

\begin{tabular}{|l|l|}
\hline Kode & \multicolumn{1}{|c|}{ Gejala } \\
\hline G001 & Gigi Lubang \\
\hline G002 & Gusi Sakit \\
\hline G003 & Gigi Linu \\
\hline G004 & Gigi Sakit jika MakMin \\
\hline G005 & Gigi Goyang \\
\hline G006 & Gusi Sakit jika Disentuh \\
\hline G007 & Benjolan pada Gusi \\
\hline G008 & Gusi Berdarah \\
\hline G009 & Bau Napas tidak Sedap \\
\hline G010 & Ada karang Gigi/Plak \\
\hline G011 & Gigi Cekot-cekot \\
\hline G012 & Gigi Linu jika Panas Dingin \\
\hline G013 & Lubang pada Sepertiga Servical \\
\hline G014 & Gusi membesar Sakit \\
\hline G015 & Gigi Nyeri \\
\hline
\end{tabular}

b. Tabel Penyakit (Diagnosa)

\begin{tabular}{|l|l|}
\hline Kode & \multicolumn{1}{|c|}{ Penyakit } \\
\hline P000 & Tidak Terdefinisi \\
\hline P001 & Abrasi Gigi \\
\hline P002 & Karies Gigi \\
\hline P003 & Abses Gingiva/Gusi Bengkak \\
\hline P004 & Gingivitis \\
\hline
\end{tabular}

c. Tabel Pembentukan Rule Sistem Pakar Diagnosa Penyakit Gigi

\begin{tabular}{|c|c|}
\hline $\begin{array}{c}\text { Jenis Klasifikasi } \\
\text { Penyakit (Diagnosa) }\end{array}$ & Masalah \\
\hline $\begin{array}{c}\text { P001 } \\
\text { Klasifikasi Penyakit } \\
\text { Abrasi Gigi }\end{array}$ & $\begin{array}{l}\text { G012 : Gigi Linu jika } \\
\text { Panas Dingin } \\
\text { G013 : Lubang pada } \\
\text { Sepertiga Servical } \\
\text { G015 : Gigi Nyeri }\end{array}$ \\
\hline $\begin{array}{c}\text { P002 } \\
\text { Klasifikasi Penyakit } \\
\text { Karies Gigi }\end{array}$ & $\begin{array}{l}\text { G001 : Gigi Lubang } \\
\text { G003 : Gigi Linu } \\
\text { G004 : Gigi Sakit jika } \\
\text { MakMin } \\
\text { G011 : Gigi Cekot- } \\
\text { Cekot }\end{array}$ \\
\hline $\begin{array}{c}\text { P003 } \\
\text { Klasifikasi Penyakit } \\
\text { Abses Gingiva/Gusi } \\
\text { Bengkak }\end{array}$ & $\begin{array}{l}\text { G001 : Gigi Lubang } \\
\text { G005 : Gigi Goyang } \\
\text { G007 : Benjolan pada } \\
\text { Gusi } \\
\text { G014 : Gusi membesar } \\
\text { Sakit }\end{array}$ \\
\hline $\begin{array}{c}\text { P004 } \\
\text { Klasifikasi Penyakit } \\
\text { Gingivitis }\end{array}$ & $\begin{array}{l}\text { G006 : Gusi Sakit jika } \\
\text { Disentuh } \\
\text { G008 : Gusi Berdarah } \\
\text { G009 : Bau Napas } \\
\text { tidak Sedap } \\
\text { G010 : Ada Karang } \\
\text { Gigi/Plak }\end{array}$ \\
\hline
\end{tabular}

\section{d. Tabel Keputusan}

\begin{tabular}{|c|c|c|c|c|}
\hline \multirow{2}{*}{$\begin{array}{c}\text { Kode } \\
\text { Gejala }\end{array}$} & \multicolumn{5}{|c|}{ Penyakit Gigi (Diagnosa) } \\
\cline { 2 - 5 } & Abrasi Gigi & $\begin{array}{c}\text { Karies } \\
\text { Gigi }\end{array}$ & $\begin{array}{c}\text { Abses Gingiva / } \\
\text { Gusi Bengkak }\end{array}$ & Gingivitis \\
\hline & P001 & P002 & P003 & P004 \\
\hline G001 & & 1 & 1 & \\
\hline G002 & & & & \\
\hline G003 & & 1 & & 1 \\
\hline G004 & & 1 & & 1 \\
\hline G005 & & & & 1 \\
\hline G006 & & & & 1 \\
\hline G007 & & & & 1 \\
\hline G008 & & & & \\
\hline G009 & & & & \\
\hline G010 & & & & \\
\hline G011 & & 1 & & \\
\hline G012 & 1 & & & 1 \\
\hline G013 & 1 & & & \\
\hline G014 & & & & \\
\hline G015 & 1 & & & \\
\hline
\end{tabular}


e. Pohon Keputusan

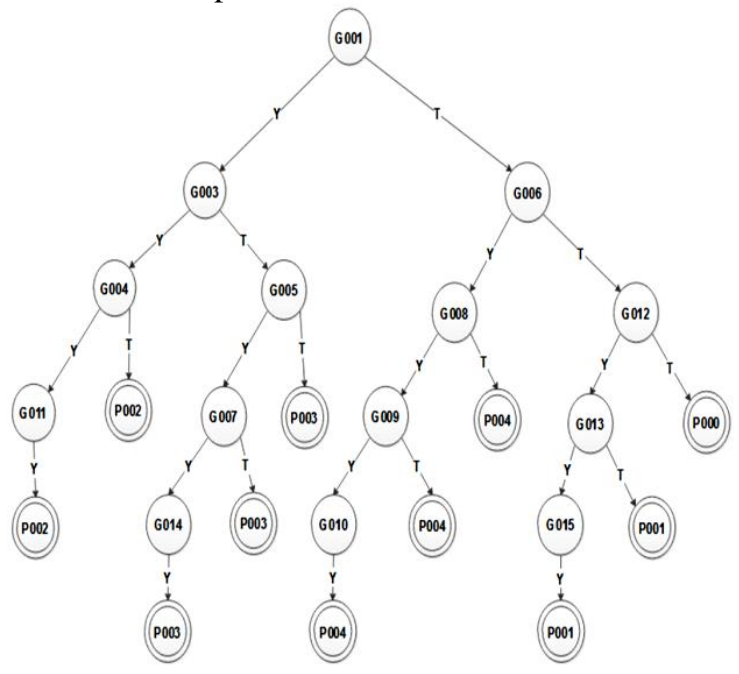

$$
O_{=\text {Penyakit }}^{\text {Keterangan : }}
$$

\subsection{Penjelasan Program}

Didalam penjelasan program ini dijelaskan tentang alur pembuatan dan kegunaan program yang dibuat beserta tampilan desain. Berikut ini tampilan - tampilan halaman yang ada dalam program yang dibuat :

\section{a. Halaman Menu Home}

Halaman pada menu home ini merupakan tampilan awal (index) saat program dijalankan, dimana dalam home ini menampilkan halaman utama saja. Adapun desain halamannya adalah :

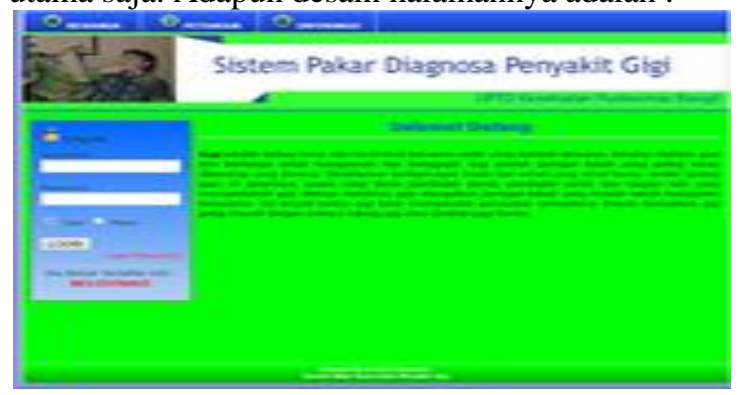

\section{b. Halaman Menu Beranda}

Halaman pada menu halaman beranda ini memberikan penjelasan tentang pengetahuan gigi. Adapun desain halamannya adalah :

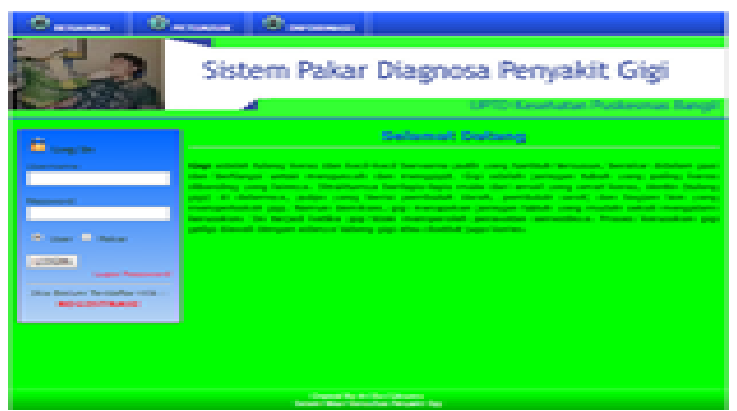

\section{c. Halaman Menu Petunjuk}

Halaman pada menu petunjuk ini memberikan penjelasan tentang fungsi dari tiap menu dan menjelaskan cara melakukan konsultasi dan mengisi Form Registrasi User (Pasien). Adapun desain halamannya adalah :

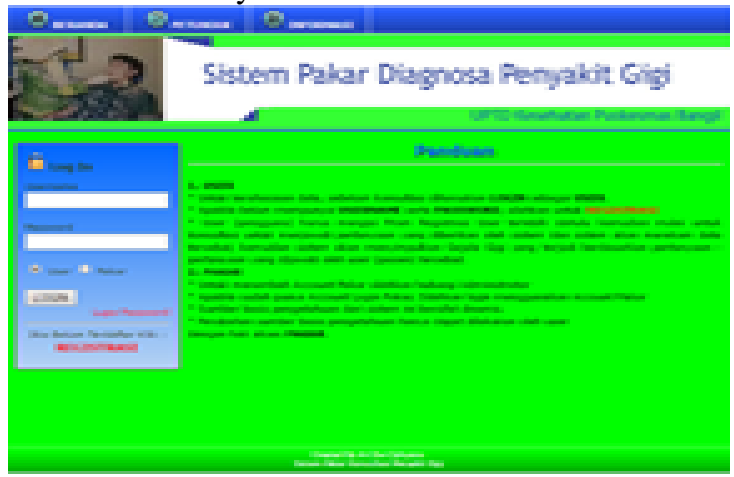

d. Halaman Registrasi User (Pasien)

Halaman pada registrasi user ini merupakan mengisi form registrasi user untuk membuat username, password baru dan mengisi biodata sebagai user (pasien). Adapun desain halamannya adalah :

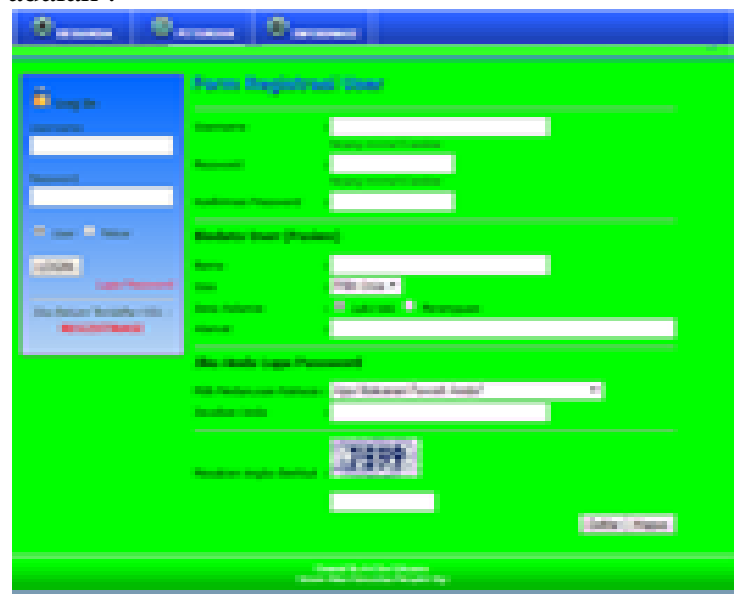

e. Halaman Menu User (Beranda)

Halaman pada menu user ini merupakan menu bagi user setelah login sebagai user (Pasien). Adapun desain halamannya adalah :

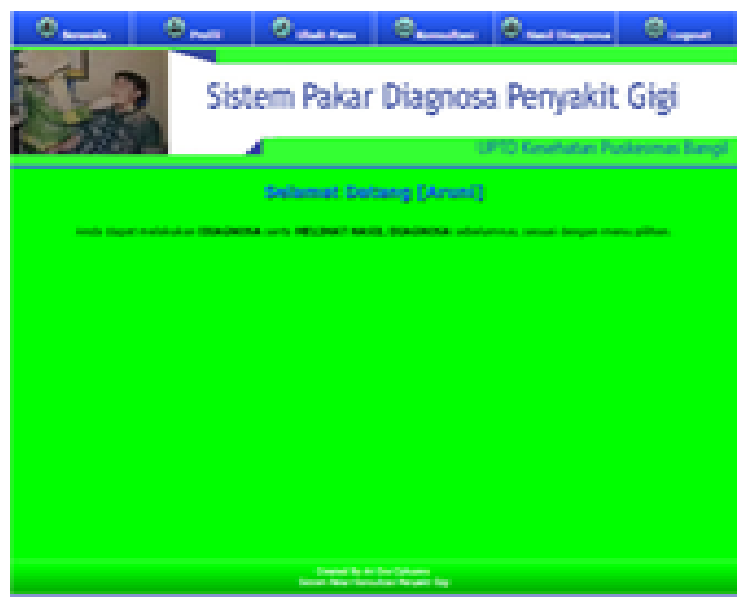




\section{f. Halaman Menu Profil}

Halaman pada menu profil ini menampilkan biodata user dan mengubah profil biodata user (Pasien). Adapun desain halamannya adalah :

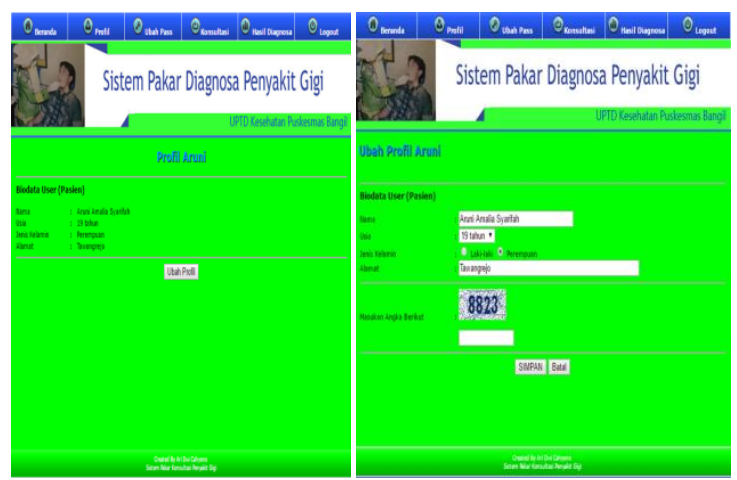

\section{g. Halaman Menu Ubah Password (User)}

Halaman pada menu ubah password (user) ini merupakan menu mengubah password (user). Adapun desain halamannya adalah :

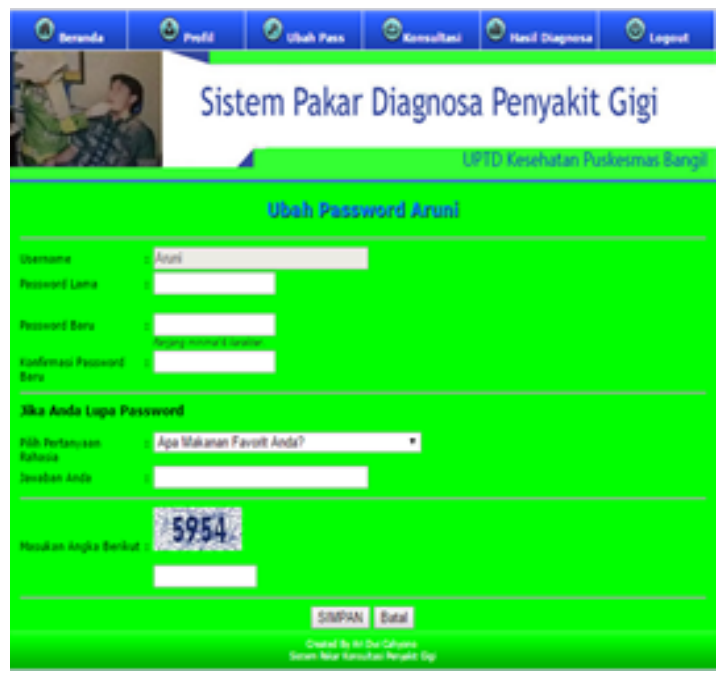

h. Halaman Menu Konsultasi (Pertanyaan)

Halaman pada menu konsultasi ini merupakan menu bagi user melakukan konsultasi tentang penyakit gigi, pertanyaan ini inti dari sistem pakar diagnosa penyakit gigi, di mana dalam proses pertanyaan ini pengguna harus menjawab Ya atau Tidak sesuai pertanyaan yang diajukan dan hal-hal gejala yang dialaminya, sampai menghasilkan jawaban yang diinginkan. Adapun desain halamannya adalah :

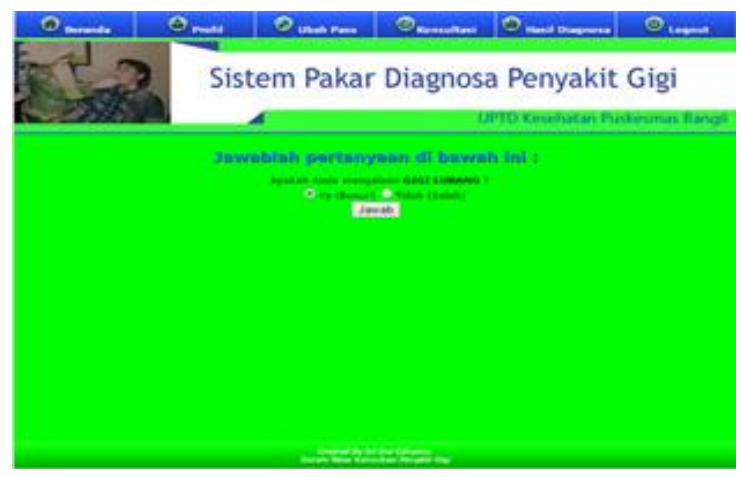

\section{i. Halaman Menu Hasil Konsultasi}

Halaman menu hasil konsultasi merupakan halaman yang memberikan informasi hasil dari masukan pengguna yang melakukan proses diagnosa atau proses / identifikasi. Masukan tersebut berupa gejala yang telah dipilih. Informasi yang diberikan pada halaman ini berupa hasil konsultasi, gejala, pengobatan, dan pencegahannya. Adapun desain halamannya adalah sebagai berikut :

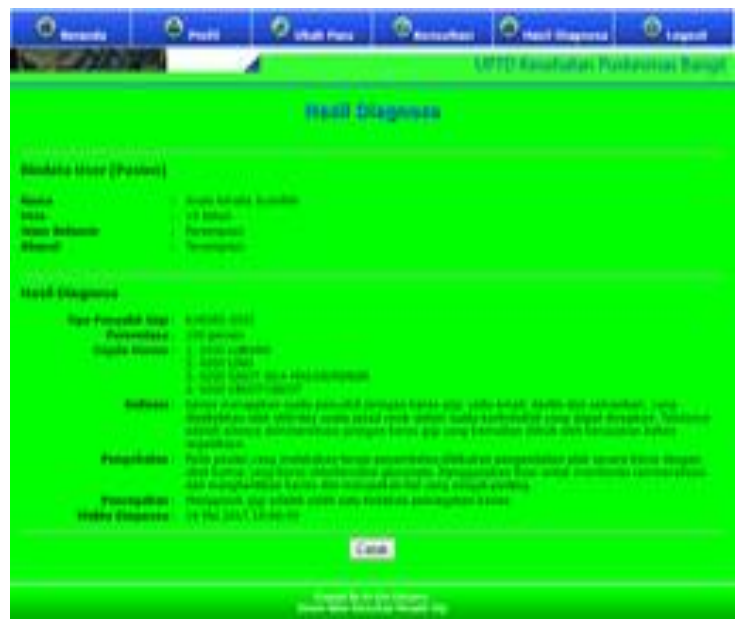

\section{j. Halaman Cetak Hasil Konsultasi}

Halaman pada cetak hasil konsultasi ini user bisa mencetak hasil konsultasi penyakit gigi. Adapun desain halamannya adalah :

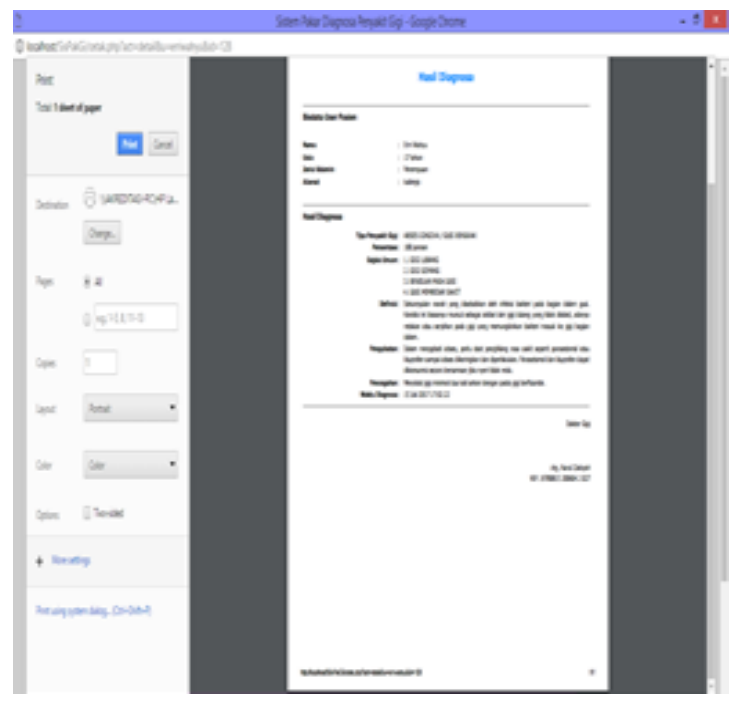

\section{k. Halaman Login Pakar (Admin)}

Halaman login admin merupakan halaman bagi admin untuk mengisikan username dan password jika ingin mengakses halaman admin berikutnya. Adalah desain halamannya adalah : 


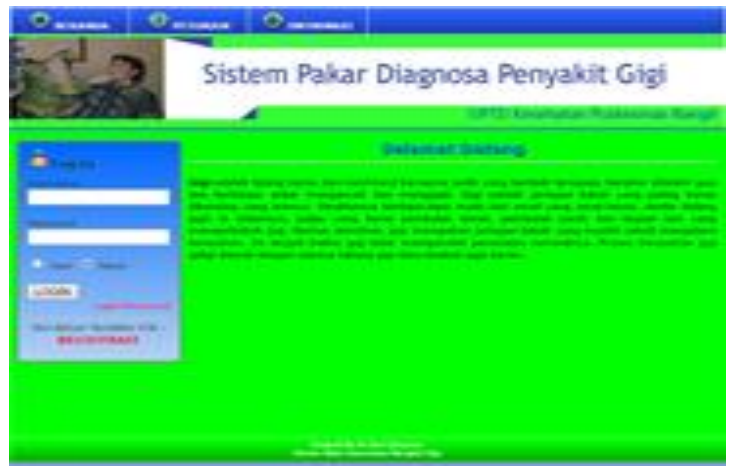

\section{Halaman Beranda Pakar (Admin)}

Halaman pada beranda ini tampilan awal beranda pakar dapat mengelola, basis pengetehuan dari sistem pakar diagnosa penyakit gigi. Adapun desain halamannya adalah :

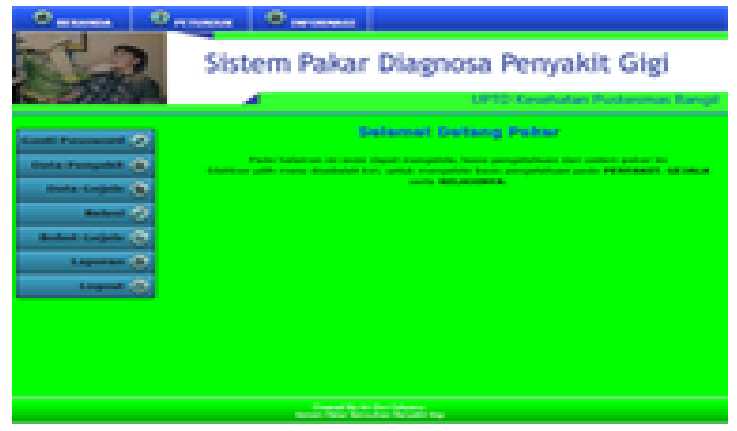

\section{m. Halaman Menu Ganti Password Pakar} (Admin)

Halaman pada menu ganti password pakar (Admin), ini merupakan menu mengubah password pakar (Admin). Adapun desain halamannya adalah :

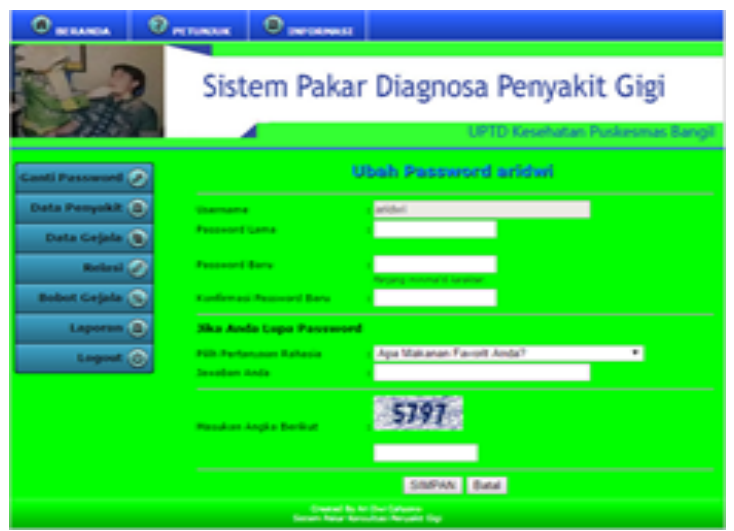

\section{n. Halaman Menu Data Penyakit}

Halaman data jenis penyakit (Diagnosa) berfungsi untuk memasukkan data - data atau fakta basis pengetahuan dalam sistem pakar untuk mendiagnosa secara dini penyait gigi yang terdiri dari input id penyakit, tipe penyakit gigi, definisi, pengobatan, dan pencegahan. Adapun desainnya halamannya adalah sebagai berikut :
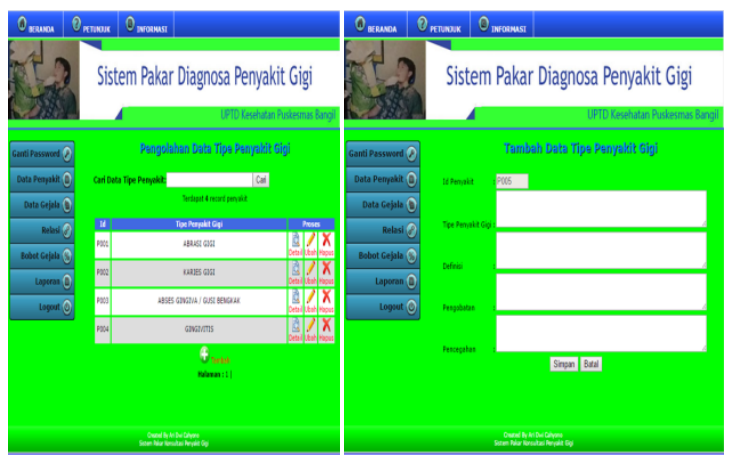

\section{o. Halaman Menu Data Gejala}

Halaman data gejala input jenis gejala (Pertanyaan) berfungsi untuk memasukkan data data atau fakta basis pengetahuan dalam sistem pakar untuk mendiagnosa secara dini penyakit gigi pada yang terdiri dari input kode gejala, nama gejala dan menentukan jawaban Ya atau Tidak pada gejala. Adapun desainnya halamannya adalah sebagai berikut :

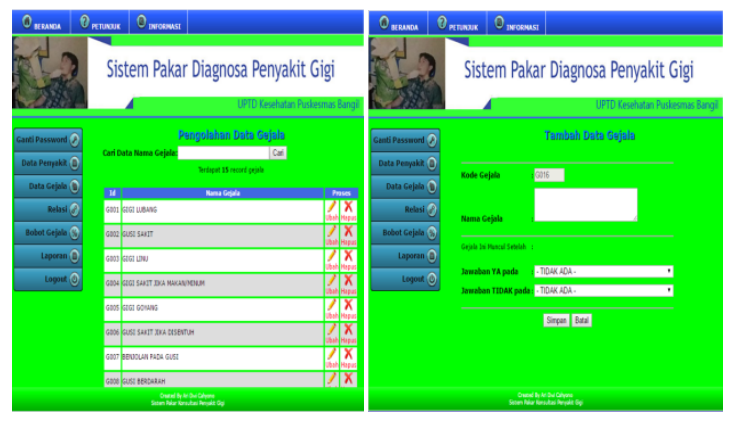

\section{p. Halaman Menu Relasi}

Halaman input relasi berfungsi untuk memasukkan data - data atau fakta basis pengetahuan dalam sistem pakar untuk mendiagnosa secara dini penyakit gigi berupa diagnosanya dengan ciri-ciri gejalanya yang kemudian disimpan. Adapun desainnya halamannya adalah sebagai berikut :

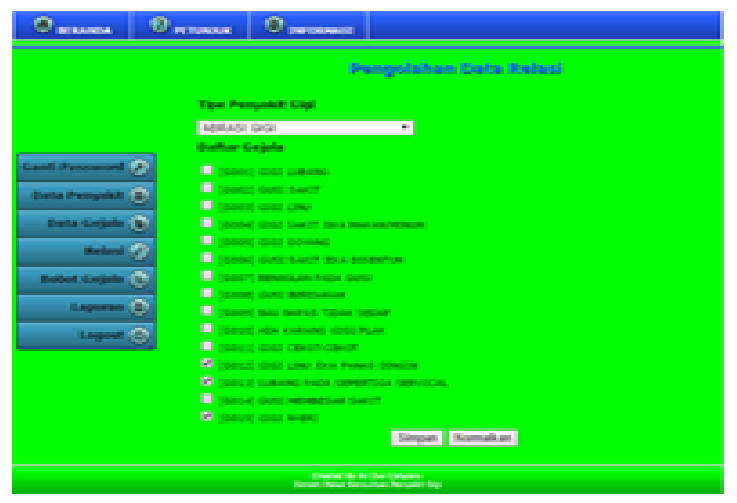

\section{q. Halaman Menu Bobot Gejala}

Halaman input bobot gejala berfungsi untuk memasukkan bobot - bobot dari gejala relasi data data atau fakta basis pengetahuan dalam sistem pakar untuk mengetahui hasil presentase diagnosa 
penyakit gigi kemudian disimpan. Adapun desainnya halamannya adalah sebagai berikut :

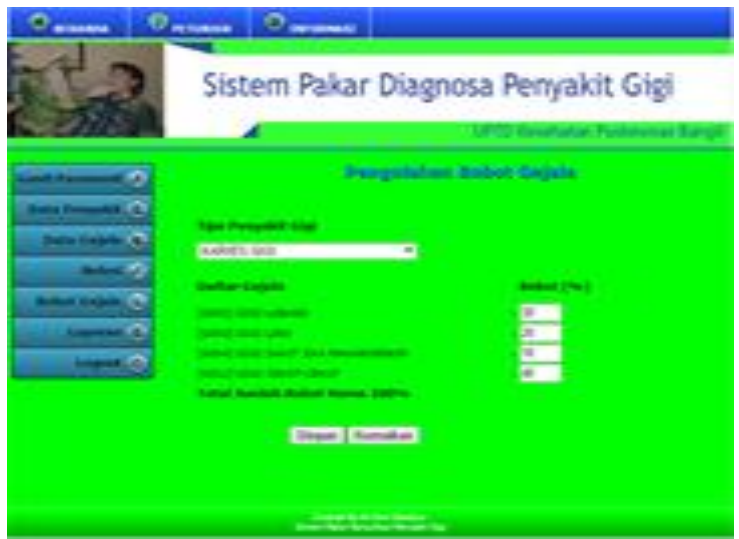

\section{r. Halaman Menu Laporan}

Halaman laporan merupakan halaman mengenai daftar - daftar data user (pasien), siapa saja yang sudah melakukan konsultasi pada sistem beserta hasil dari konsultasinya. Adapun desain halamannya adalah sebagai berikut :

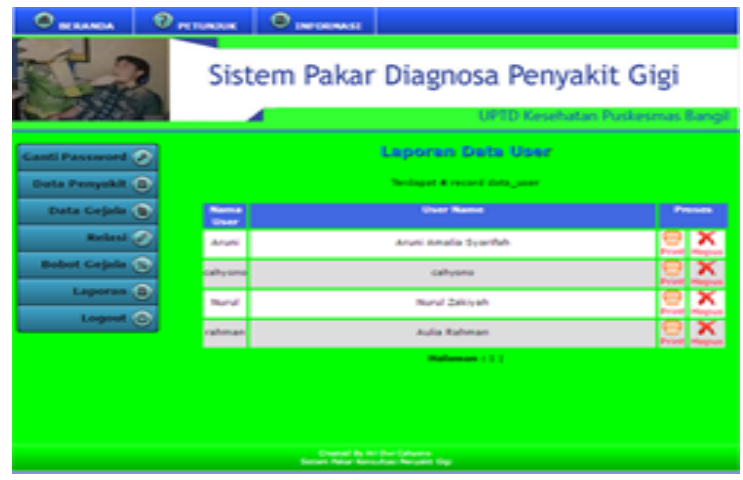

\subsection{Pengujian Sistem}

Pengujian perangkat lunak adalah elemen kritis dari jaminan kualitas perangkat lunak dan mempresentasikan kajian pokok dari spesifikasi, desain, dan pengkodean. Pengujian dilakukan dengan cara menggunakan kuesioner.

Metode ini merupakan pengujian yang dilakukan secara objektif dimana program aplikasi diuji secara langsung ke lapangan dengan membuat kuisioner mengenai kepuasan pelanggan pasien masyarakat umum dan teknisi lapangan.

Pengujian mengenai keakuratan dan kelayakan sistem aplikasi ini, berdasarkan atas beberapa pertanyaan yang menyinggung permasalahan tersebut, hal yang ditanyakan dalam kuesioner adalah mengenai materi atau informasi pada aplikasi, akurasi kesimpulan dan solusi serta kelayakan sistem.

Sehingga dapat disimpulkan dari hasil kuisioner secara menyeluruh menunjukkan bahwa, program aplikasi sistem pakar diagnosa penyakit gigi ini memiliki keakuratan dan kelayakan yang baik, karena hampir dari semua pertanyaan yang diajukan, responden memilih kategori baik.

\subsection{Analisa Sistem}

Analisa sistem merupakan kegiatan untuk memahami dan spesifikasi dengan detail apa yang harus dilakukan oleh sistem dan proses mengumpulkan dan menginterpretasikan kenyataan-kenyataan yang ada, mendiagnosa persoalan dan menggunakan keduanya untuk memperbaiki sistem (Hanif Al-fatta: 24).

Analisa data hasil penelitian merupakan tindak lanjut atau survei. Analisis ini penulis gunakan untuk mengecek kelengkapan data dan memudahkan analisa pemecahan masalah. Pengumpulan data dengan cara studi literatur, observasi, dan browsing dirasa perlu dilakukan jika dalam tahap analisasi data ini masih dirasakan kekurangan data tertentu. Tahap - tahap analisa data adalah sebagai berikut :

\section{a. Menganalisa Kebutuhan}

Arah dan tujuan sistem pakar diagnosa penyakit gigi ini adalah untuk membantu pegawai dokter gigi UPTD Kesehatan Puskesmas Bangil serta semua masyarakat yang minim pengetahuannya tentang mengatasi penyakit gigi, untuk mengetahui cara mengatasi dan mencegah sakit gigi dengan benar dan tepat.

\section{b. Menganalisa Cara Kerja Program}

Aplikasi sistem pakar diagnosa penyakit gigi ini terdapat 3 menu utama yang masing-masing memiliki fungsi untuk menu halaman utama berfungsi sebagai halaman beranda tentang pengertian gigi, petunjuk user (pengguna) dan informasi tentang pengetahuan sistem pakar gigi. Untuk menu user ada 5 pertama beranda sebagai awalan pemberitahuan, kedua profil/biodata user, ketiga ini user bisa melakukan mengubah password yang terbaru.

Menu konsultasi ini adalah menu yang di mana user atau pasien melakukan konsultasi sesuai dengan gejala yang dirasakan user (Pasien). User akan disajikan beberapa pertanyaan yang di mana user harus menjawab Ya atau Tidak, sampai menemukan hasil diagnosa yang diinginkan. Jika relasi dalam konsultasi tidak ditemukan maka user akan dimunculkan pemberitahuan bahwa hasil kesimpulan diagnosa tidak mengalami jenis penyakit gigi tipe apapun, disebabkan tidak ada gejala yang dialami. Untuk menu admin digunakan untuk admin menambah, merubah atau menghapus gejala/pertanyaan, konsultasi atau diagnosa serta relasi juga bobot gejala. Serta di dalam menu admin tersimpan laporan siapa saja yang mengisi data pasien dan melakukan konsultasi.

\section{c. Menganalisa Laporan}

Untuk proses pembuatan laporan, tidak memiliki kendala. Untuk data tentang penyakit gigi didapat dengan mudah dari UPTD kesehatan Puskesmas Bangil. Serta pengetahuan lain didapat 
dari dokter gigi di UPTD Kesehatan Puskesmas Bangil.

\section{d. Menganalisa Teknologi}

Setelah dilakukan uji coba sistem, aplikasi sistem pakar ini berjalan dengan baik sesuai dengan aturan dan data yang dimasukkan. Namun masih perlu penambahan informasi atau data yang lebih spesifik dan akurat lagi. Serta perlu dikembangkan lagi dalam hal tampilan serta kemudahan dalam penggunaan.

\section{KESIMPULAN}

Berdasarkan permasalahan yang telah dibahas dan diselesaikan melalui laporan ini, maka terdapat beberapa kesimpulan :

a. Sistem pakar ini, memberikan kemudahan kepada pasien untuk melakukan konsultasi.

b. Sistem ini memudahkan admin untuk mengelola data-data gejala beserta penyakitnya dan data pasien.

c. Sistem pakar ini sangat bermanfaat dilihat dari hasil kuesioner yang menyatakan sangat bermanfaat.

d. Sistem pakar ini bisa dijadikan sebagai dokter sementara.

\section{Saran}

Setelah mengembangkan sistem pakar ini, ada beberapa saran yang harus diterapkan guna pengembangan sistem pakar lebih lanjut :

a. Perlu pengembangan sistem pakar diagnosis penyakit gigi dengan hasil keputusan yang lebih akurat. Seperti hasil diagnosa intensitas penyakit gigi yang terjadi. Lebih diperhitungkan dengan matang.

b. Pengetahuan sistem pakar diagnosis penyakit gigi kiranya dapat semakin diperkaya dengan penambahan kompleksitas gejala dan solusinya.

c. Sistem ini masih dapat dikembangkan dengan menggunakan metode lain yang lebih akurat untuk mendiagnosis intensitas penyakit gigi.

d. Sistem ini dapat dikembangkan lebih lanjut dalam pemanfaatan media internet atau sistem yang berbasis web online.

e. Dilakukan pengembangan program sejenis dengan gejala domain yang lebih luas.

f. Untuk solusi dan pencegahan serta pengobatan lebih lanjut sehingga dapat menghasilkan penanganan yang maksimal, sebaiknya user (pasien) rutin berobat di tempat UPTD Kesehatan Puskesmas Bangil terdekat.

\section{PUSTAKA}

Ali, Nur. 2015. Sistem Pakar Diagnosa Penyakit Gigi Di Klinik Gigi Apotek 128. Surakarta: Teknik Informatika

Alodoktor. 2016. Pengertian Sakit Gigi. http://www.alodokter.com/sakit-gigi, (Diakses 16 Desember 2016)

Bejo, Orang. Pengertian Metode Forward Chaining. http://www.orangbejo.com/2015/11/pengerti an-metode-forward-chaining dan.html, (Diakses 16 Desember 2016)

Cahyono, Fendy. 2015. Pembangunan Aplikasi Sistem Pakar Diagnosa Penyakit Gigi Dan Mulut Pada Manusia. Pacitan: Teknik Informatika

Dental 55, Bandung. Penyakit Gigi (Umum). Diambil dari https://dental55.com/penyakit-gigi/penyakitgigi-umum/. Diakses (26 Maret 2017)

Kurniawan, Budi. Aplikasi Sistem Pakar Berbasis Web untuk Diagnosa Penyakit Gigi dan Mulut. Skripsi. Jakarta : Teknik Informatika Fakultas Sains dan Teknologi, Universitas Islam Negeri Syarif Hidayatullah Jakarta.

Nugroho, Bunafit. Membuat Aplikasi Web : Sistem Informasi Perpustakaan dengan PHPMYSQL dan Dreamweaver. Penerbit Gava Media. Yogyakarta : Teknik Informatika, PTS Yogyakarta.

Saputra, Agus. Panduan Praktis Menguasai Database Server MYSQL. Penerbit PT Alex Media Komputindo. Jakarta.

Taufik. 2015. Rancang Bangun Aplikasi Sistem Pakar Diagnosis Perilaku Api pada Kebakaran Berbasis PHP dan MySql dengan Metode Forward Chaining. Skripsi. Bangil : Teknik Informatika, STMIK Yadika Bangil.

Tutorial Komputer, Pengertian MySQL beserta kelebihan dan kelemahannya. http://www.teorikomputer.com/2015/10/pen gertian-mysql-beserta-kelebihan-dan.html, (Diakses 25 Maret 2017) 